\title{
OVERTHROWING THE STATUS QUO: INTERPRETING WOLE SOYINKA'S THE BACCHAE OF EURIPIDES FROM A MARXIST PERSPECTIVE
}

\author{
Norbert Oyibo Eze
}

Ph.D.Senior Lecturer, Dept. of Theatre And Film Studies, University Of Nigeria, Nsukka

\begin{abstract}
Certain critics of contemporary Nigerian drama represented by Abiola Irele, for example, seem to place the plays of Wole Soyinka, the 1986 Nobel laureate on literature, squarely within the confines of ritual aesthetics, in terms of dramatic taxonomy. Although ritual, especially Ogunism, exerts a huge influence and, no doubt, constitutes a major master code for interpreting a play like The Bacchae of Euripides, this paper argues that the religious elements in this transnational play merely serve as a camouflage for the exploration of class struggle. Class consciousness, though expressed through religious symbolism, is given much force and weight in the play from its beginning to the end that it seems to be the principal theme of this play. In the text, the masses knowledge of their position as not given, constrains them to remain steadfast and pushful until they overthrow the status quo through mass revolution, thereby securing unfettered freedom for themselves. In the light of the foregoing, this paper will attempt to interpret The Bacchae from Marxist perspective in order to show that not all Soyinka's plays lack solid class ideology.
\end{abstract}

Keywords: Overthrowing, Bacchae, Marxist, Soyinka.

\section{INTRODUCTION}

Tiresias: Let's leave mythology aside. Think only of

And come to terms with what we know.

Pentheus: And what do we know apart from your casuistry?

Tiresias: Our human condition ... (259).

The above excerpt from the dialogue between Tiresias and Pentheus in the early part of The Bacchae of Euripides seems to suggest that in the play, mythic thinking and religious activities are used as a veneer to examine human material conditions. This study employs Marxist theory to critically analyze and interpret the meaning of the play. It argues that the class structure of human society represented by the world of King Pentheus, on one hand, and the world of the slaves and helots, on the other, as well as the tensions and mutual hostilities they generate, which eventually leads to the killing and toppling of the status quo, follow a dialectical process. Indeed, the text suggests that the overthrow of the establishment annuls both classes for the new order that emerged is a classless society. The slaves seem to have been liberated into the kingdom of freedom for when Kadmos orders them to bring down the severed head of Pentheus, they "all retreat and look down" [306]. This action of the slaves show that time is no longer what it used to be. It signifies the death of the old order and emergence of freedom for the downtrodden. 


\section{MARXIST INTERPRETATION OF THE BACCHAE OF EURIPIDES}

The class structure of human society, of which its annulment is the principal goal of Marxism, is the main human condition that confronts us as we open The Bacchae for perusal. The first stage direction of the play is clear about this subject of human condition:

To one side, a road dips steeply into lower background, lined by the bodies of crucified slaves mostly in skeletal stage. The procession that comes later along this road appears to rise almost from the bowels of earth... In the foreground the main gate to the palace of Pentheus. Further down and into the wings, a lean - to build against the wall, a threshing floor. A cloud of chaff, and through it, dim figures of slaves flailing and treading. A smell of and sweat of harvest (235).

The picture painted above is that of two diametrically opposed classes, one, a suffering, toiling, oppressed, dehumanized and down-trodden, represented by the crucified and labouring slaves, and the other, a dominant, suppressing and exploitative class represented by Pentheus. The first intriguing and shocking discovery of Karl Marx and his adherents, in the study of human civilization and development, is the reduction of the human society into two discernible but unequal social formations - the exploiter and the exploited. In the preface to the 1883 German Edition of The Communist Manifesto, Fredrich Engels (marxist.org) notes that:

ever since the dissolution of the primeval communal ownership of land, all history has been a history of class struggles, of struggles between exploited and exploiting, between dominated and dominating classes at various stages of social evolution; that this struggle, however, has now reached a stage where exploited and oppressed class (the proletariat) can no longer emancipate itself from the class which exploits and oppresses it (the bourgeoisie), without at the same time forever freeing the whole society from exploitation, oppression, class struggles.

For the Marxists, according to Kamenka (1979), "Man is potentially the only subject in a world of objects and anything that turns him into object, subordinates him to powers outside himself, is inhuman". A major human condition that horrifies the Marxists, which is expressed deeply in The Bacchae, is the issue of slavery. In the text slavery is used to illuminate total abasement of a class. It is used as a tool for extreme alienation of man from his kind. In the play, the slaves are shown to lack any right to self-determination. They are confined to a solitary place from where they are drawn to work or to be flogged to death as objects of sacrifice in a monstrous ritual, notwithstanding the fact that they provide the labour that sustains the economy of the nation.

However, the text is full of sentiments suggesting that the slaves resent their inhuman treatment. The conversation between the slave leader and the Herdsman exemplifies this:

Leader: $\quad$ Flogged to death? In the name of some unspeakable rites?

Herdsman: Someone must cleanse the new year of rot of the old or, the world will die.

Leader: Why us? Why always us?

Herdsman: Why not?

Leader: $\quad$ Because the rites bring us nothing! Let those who profit bear the burden of the old year dying.

Herdsman: Careful (Points to the row of crosses) The palace does not need the yearly feast of Eleuis to deal with rebellious slaves (237).

This brief discussion between the slave leader and the Herdsman demonstrates that the slaves never see their state of existence as given, and hence do rumble and rebel from time to time even though perceived acts of insurrection frequently earn them crucifixion.

The slave question is a form of contradiction that is the first necessary condition for change because servility creates a relationship of mutual hostility between the master and the slaves. It is, therefore, argued that in The Bacchae, Dionysos is a revolutionary force that comes to give impetus to the struggle of the downtrodden class to liberate itself from a "pre-industrial kind of society where hardship and suffering and waste of human resources" (Marxism and Ethics 22) are the order of the day. Dionysos comes to set the masses free from King Pentheus who has become drunk with power and who wants all his orders to be hallowed while he crushes the people's struggle for self-determination.

Dionysos' reaction to Pentheus's power drunkenness gives psychological boost to the masses enabling them to become increasingly disquieted with their existential condition. The slaves and the helots see Dionysos as a symbol of change and emancipation. Before the emergence of Dionysos, the atmosphere was pervaded with all kinds of restrictions. People were in chains under an authoritarian leader who unabashedly denies them 
their fundamental human rights, including the rights to life, freedom of worship and speech. Pentheus is portrayed as a personification of oppression and suppression. His very first statement in the play suggests that he abhors freedom of worship. On learning in his trip abroad that Thebes has accepted a new god, he becomes furious and on his return, orders that adherents of the god should be "Hunted down. Chained and caged behind bars of iron" (256). And for invading his territory, he promises Dionysos the following punishment:

I'll initiate his balls from his thighs once we have him safely bound. I'll initiate that head away from his body.... I' II bring an end to the cunning subversion (257).

The Bacchae of Euripides is one of the plays Soyinka wrote during his 1971 - 1975 self-exile. Gibbs (1986) in Critical Perspective on Wole Soyinka, argues that the play is written partly from an anxiety to make a political comment". Indeed, Soyinka's adaptation associates Pentheus "very strongly with death, repression and megalomania" (III) in his handling of perceived offenders. In his PhD thesis, Eze (2014) observes that "Pentheus is shown throughout the play to be bloodthirsty, ruthless and too impatient with criticism" (132). As a political overreacher, he appears fixated in his thinking about power, always acting the part of a lion. His personality is never at any point tempered with humanity. In fact, he is an arrogant leader to whom "power is all that matters' (The Bacchae 261). He is not ready to countenance any form of opposition or rivalry. As his grandfather, Kadmos tells us, his name means sorrow, and throughout the play, he plans sorrowful endings for those that he perceives to be radicals. He seldom makes any statement against these people without punctuating it with chain and pain-infested words. Dionysos harps on this when he tells him:

You Pentheus because you are a man of chain. You love chains. Have you uttered one phrase today that was not hyphenated by chains?/You breathe chains, talk chains, think chains.

Your world is bound in manacles.../Even in your repose you are a cow chewing /the cud, but for you it is the molten iron/issuing from the furnace of your so - called/Kingly will (284).

The above opinion portrays Pentheus as an epitome of bondage. In his Theban society, the masses cannot even speak freely. For airing his view about Dionysos, Tiresias gets a severe punishment from the king who orders his attendants to:

Find the place where this prophet sits/Faking revelations out of bird song. Go,/Pry it up with crowbars, heave it over/Upside down. Demolish everything you see./Throw his fillets out to the wind and weather (262).

And when an old attendant wondered why such a cruel penalty should be meted to the prophet for merely expressing an opinion, Pentheus not respecting age deemed sacrosanct by the land, "fetches him a slap which knocks him flat" (263). Of course, such inhuman indifference, hitting down an old man as well as demolishing the house of a sage, is variously and openly condemned by the slaves as the summit of corrosive madness. In another vein, the Herdsman who reports the activities of the Bacchantes on the mountain to Pentheus does so under a solicited oath. He solicits to speak freely under oath because "Master, you have a cruel temper/We, your subject/Know it to our cost/And all too often" (278).

In fact, Pentheus's oppressive rule had earlier constrained Kadmos to regret to have handed power to him. He told Tiresias:

I don't understand it. I am restless with a thousand schemes. Why should I keep thinking now I should never have left the throne to Pentheus?// know he will do something wrong.../There are still soldiers loyal to me./We could stage a coup d' et at (254).

In fact, Pentheus's rage for power, his mistreatment and incarceration of a god, shows that he does not know the limit of his power and this seems to leave everyone gasping for breath. The African slave who sees Dionysos as the soul of liberty and the seed of a new order laments what appears to be double tragedy for him:

Why am I rejected? Why am I a second time rejected O blessed Nile. First banished from your banks into this city, a slave. And now to see the promise broken, the messenger of Bromius in chains heavier than mine! $\{271\}$.

It is because the situation in Thebes at the present is intolerable that makes Tiresias to foresee "uprising "and "bloodshed" (246).

The idea of losing power to maintain control causes Pentheus to become paranoid, even schizophrenic. He must regain absolute authority by all means and is ready to sink everyone, to destroy all who seem to stand on his way to fulfil this burning desire, including his own mother. His conversation with Dionysos on their way to the mountain makes this clear: 
Pentheus: Mind you, I shall not forgive Tiresias,

Or grandfather. They should have set

A good example and save me all this bother.

Dionysos: You will meet them on your way.

Your grandfather/shall be cruelly punished.

And Agave.

Pentheus: She most especially. My own mother

What a disgrace? /Hope we don't find her

Doing something really disgusting at those revels

I would be forced to kill her-for the honour

Of the house of Kadmos.you understand? (290).

The above conversation shows that Pentheus considers power to be above even filial love. His urgent need to quell opposition at all costs propels him to give primacy to passion over and above reason and to show blatant disregard to wise counsels as well as to be hasty in actions and decision-making. His love for power makes him to hold both men and god in contempt. Indeed, he is portrayed in the text as a deeply flawed ruler who is ignorant of knowledge usually gained from self-control. Both Kadmos and Tiresias try to guide him on the path of reason by letting him to know at least the limitations of man as a mortal. On this issue, Tiresias tells Pentheus:

If only you would lose this notion that power

Is all that matters in the life of man

Do not mistake for wisdom these fantasies

Of your sick mind. Abandonment?

Restraint is something people must practise

Themselves. It cannot be imposed...Answer me, is control not built/upon self-knowledge? (261)

Instead of seeking knowledge about the nature of mankind, Pentheus's position as a king and his gift of power of expression constrain him to become arrogant and self-conceited which enable him to utter abominable and unspeakable words that foreshadow his destiny. According to Maduako (1991), "when Pentheus submits himself gradually and yet inexorably to the charm of the Dionysian magic, he accepts a cup of wine from the god and drinks it, thereby accepting his fate as a scapegoat" (259). For me, this humiliating acceptance is a proof that knowledge will forever govern ignorance. Maduako (1991) argues that handing power over to Pentheus instead of Ichion, his father:

...might be deliberate since the dramatist can then highlight Pentheus as an inexperienced young man, who sticks doggedly to his own views in spite of all evidence to the contrary. For Pentheus betrays a stubborn temper that is inhuman. Not even his grandfather's pleadings nor Tiresias' reasoning can persuade him to reconsider his stand on Dionysus. His tragic flaw is his rigid commitment to principles, whereas balance is said to hold the key to life.

Etherton (1982), in the Development of African Drama, argues that "Pentheus represents the nobility sustained by established order: the law, the army and of course the mysteries". However, the coming of Dionysos and the freedom it symbolizes has gripped the minds of the people of Thebes, causing all those who suffer under Pentheus's autocratic government-the helots and the slaves especially who have been constantly in active rebellion, to form a formidable alliance with Dionysos in order to secure their freedom. Pentheus's commitment to continuity is countered by the people's resolve to be emancipated. A lot of energy is released on both sides. In fact, Etherton stats that "the more repressive Pentheus becomes... the more violent becomes the reaction against him" (231).

Marxism is interested in change and in men making their own history. But as Baxandall and Morawski (1977) observe, "Men make their own history, but they do not make it just as they please; they do not make it under circumstances chosen by them but under circumstances directly encountered". The lower status accorded to women in Thebes and the inhuman condition under which the slaves work and live constrain them to become revolutionary, to muster all the courage at their disposal, no matter the cost, in a struggle to pull down a wall of inhibition that is Pentheus.

For the slaves, Pentheus is not a man but, "A beast run wild./A crop of dragon's teeth/That earth has never tamed with nursing (272). A man of this nature is not dealt with lightly. He must be confronted if the slaves must actualize their dream of freedom. This is the reason they openly rumble, not deterred by the dungeon nor crucifixion. They make supreme sacrifice from time to time because as one of them notes, "A scent of freedom is not easily forgotten" (236). 
In presenting the logic of their rebellion, the slave leader tells one of the slaves who wondered that they have gone far already in challenging the status quo that, "when the present is intolerable, the unknown harbours no risks" (240). The implication is that the need for a new order is not a matter of choice but necessity.

For Marx, the human essence has no true reality. Humans are plastic and shaped by their circumstances especially the economic circumstance under which they live. In The Bacchae, Pentheus and the slaves are committed to opposite sets of irreconcilable truth. What they consider reasonable and good have no meeting point. The social circumstances that characterize the world of Pentheus and that of the slaves and helots are contrary to each other. Pentheus is governed by the law of absolutism and monopoly and for him, order must remain as it is because in the prevailing circumstance or order, he not only enjoys the "necessaries" of life, but determines how everyone else must live. And to realize this, he ensures that the condition of the other class grows worse by the day. The order that Pentheus cries out that he must have is the order that makes the slaves and the helots persona non grata, and subjects them to forced labour and ritual objects. On the other hand, the order which the slaves want is that which will set them free from bondage and servitude and grant them opportunity for self-determination. Pentheus is not ready to acquiesce to this type of order and, therefore, uses the forces of the state to suppress any form of threat.

Violence becomes inevitable because both in thinking and action, Pentheus is not disposed to any form of change. For the oppressed in the play, violence is a means to an end, one step they need to take in darkness that will usher them into the marvellous light of a new and better existence. In The Phenomenology of Mind, Hegel (1967) expresses the view that:

The law again, which is opposed to law of the heart is divided from the heart and exists on its own account. Mankind which is bound to it does not live in blissful unity of the law of the heart, but either lives in dismal separation and suffering, or at least in deprivation of the enjoyment of itself in obeying the law.

What is implied in the above statement is that any condition that chains man down and makes it impossible for him to actualize himself is a violent ordinance of the world, and that any means employed to resist it is justified, as long as the goal is, according to Hegel, to "do away with the suffering arising from it as well as to bring about the welfare of mankind" (393). For the Marxists, the oppressed participation in violence does not make them irrational. For them, violence is a social communicative praxis used by the deprived to reduce sensory overloading, exert pressure on political institution and as is the case with The Bacchae of Euripides, to overthrow oppressive regime and to secure freedom for the exploited and suppressed.

For the slaves and especially the African slaves who, appear to be doubly alienated, the emergence of Dionysos is a sign of their deferred freedom coming to a head. The slave leader reassures the rest of this by telling them:

You hesitant fools! Don't you understand? Don`t you know? We are no longer alone-/Slaves, helots, the near and dispossessed!

The master race, this much vaunted dragon sprawn,/Have met their match./Nature has joined forces with us (240).

In the text, Dionysos is posited as a reconciler of "the warring universe" (251), an elixir and equalizer. The $1^{\text {st }}$ Bacchante explains that Dionysos is the one "who opened our eyes to the freedom of souls, to the liberation of waters" (246). And with respect to the role of the god as a leveller, Tiresias posits:

He has broken the barriers of age, the barrier of sex or slave and master. It is the will of Dionysos that no one be excluded from his worship (255).

The $1^{\text {st }}$ Bacchantes and Tiresias's statements above are enlightening for they seem to open the masses' eyes of understanding, constraining them to become fully aware that, "Thebes has fallen out of love" and that "the hour we long awaited" when "what is hidden must... come to light, (253), is now. This suggests that the proletarian class has become conscious of "its position and needs" (Eze 73). What is hidden that has come to light is the bourgeois ideology, which, according to Macintyre (1971), falsifies reality by assuming that existence is "solid and determinate, a matter of existence filling out pre-existing roles, a matter of existence filling out an already determined essences. The masses' consciousness of the fact that their suffering is not supernaturally imposed but man-made, pushes them to become restive and to get ready to deliver a precise judgement against Pentheus who has shown himself to be "a symbol of mindless aristocracy (Williams 38). Indeed, the theory of historical materialism seems to issue forth in action here. Discussing the slaves' growing political consciousness Muoneke (1980), states that Soyinka portrays the slaves as moving gradually from a cautions subservience to Pentheus to an open allegiance to Dionysos" (25).

Historical materialism is a consummate theory formulated by Marx and Engels for the purposes of arming mankind especially the working class with knowledge about historical development. It is a scientific attempt to 
relate history to human activity. The theory posits that man can know the world and the laws that guide its development and operation, and that he can employ this knowledge in radically transforming the world and his own material condition of existence. Through this doctrine, Marx and Engels hope to make the proletariats to become fully aware of their position and need, the need for emancipation and self-determination. It seems to me that it is the new political awareness that compels the slaves to destroy "their prison and chains in the divine dance of joy" (Moore 150). Their mounting hostility and revolutionary activity get to the peak at the mountain where through the manipulative activity of Dionysos, they join forces with the helots to topple the authoritarian government of Pentheus by killing and dismembering him body. The dance of Dionysos is the dance of freedom and emancipation.

Dieke (2010) articulates what Dionysos represents in "four symbolic frames: the nihilistic, the tragic, the Dionysian and finally the frame of the heroic individual". For him, the nihilistic is the frame of despair and anxiety which emerges from what Ruy (1968) refers to as the "decomposition of culture". Dionysos vents this nihilistic anger on Pentheus by burning down his palace and secondly by influencing his brutal decapitation. Nihilism for Dieke is "not destructive but tragic for it contains within its negative ideology and rhetoric the very basis for regenerative growth" (81). In The Bacchae, the killing of Pentheus paves way for a new culture where freedom exists for all.

Dieke further states that the nihilistic and the tragic visions are linked by a certain ineffable complementarity, which Nietzsche finds Dionysus to symbolize. Illuminating the personality of Dionysos in detail, Dieke (2010) writes that:

Dionysus is Prometheus, Faust, Zarathustra; he is skeptic, critic, destroyer, builder, and creator. He is the "Ur-Eine" primal oneness and the ground of being, ever contradictory and ever suffering; he is Schopenhauer's eternally striving will. ${ }^{3} \mathrm{He}$ is also the will to power, the will to overcome, to affirm and to create. Dionysus is Nietzsche's symbol of modern man who has lost all traditional values and believes and faces nihilism and despair. But he also represents the heroic individual who overcomes nihilism and finds a new meaning of life, one that Nietzsche designates as Dionysian and tragic (83).

In The Bacchae, we find Dinysos arrested, chained, shaved and imprisoned. We see him setting himself free from all manner of threats from Pentheus. We find him indulging in nihilistic actions of burning down Pentheus's palace and manipulating his odious death. He turns the tide against the king while liberating the slaves and the helots that have long been subjected to inhuman treatment by the king.

The state of affairs in Thebes after the death of Pentheus equals to the Marxist perception of an ideal human society as a classless society, where the whole of humanity, according to Stefan Morawski, comes into the "Kingdom of freedom" (Marx and Engels on Literature and Art 7). In examining the state of social formation after the exit of Pentheus, Obi Maduako quotes Nietzsche to have written that:

Not only does the bond between man and man come to be forged once more by the magic of the Dionysian rites, but nature itself, long alienated and subjugated rises again to celebrate the reconciliation with his prodigal son, man... Now the slave emerges as a freeman; all the rigid hostile walls which either necessity or despotism has created between men are shattered (250).

Classless society which appears to be the new order that emerges at the end of the play is in agreement with Marxian disposition. What is remarkable is that Cultural Revolution in the text followed a dialectical pattern and never results from pastiche of events. In the first instance, the dominant class bred oppression, exploitation, suppression and wastage of human resources. The lives of the people who drive the economic activities were daily dissipated. This unacceptable social arrangement encourages rumbling among the slaves and the result is open confrontation. Obi Maduako maintains that "the confrontation between the rebel and authority causes a crisis out of whose ruins emerge a new order" (250). This writer agrees with Maduako that in The Bacchae of Euripides as adapted by Wole Soyinka, "The myth of the god is a self-conscious factor in the revolutionary dynamics for social change" (251). It is a camouflage to make a bold statement about political overreaching, exploitation and suppression of the masses and the tedious tasks involved in the quest for freedom and selfdetermination. It is important to note that the slaves are never content with their material condition and their knowledge that it is man-made makes them to rumble and to complain openly. This is why they quickly and boldly accept the opportunity Dionysos offers them to regain their freedom.

\section{CONCLUSION}

The central argument of this paper is that in spite of its mythic veneer, Soyinka's The Bacchae of Euripides is politically impacted, as it were, by the Marxist ideology. The first issue of Marxist significance is the demarcation of the world of the play into two antagonistic classes which represent the Marxist proletarian and bourgeois 
classes. While in the text Pentheus is posited as an overreacher, drunk with power, ever eager to maintain control, the slaves which represent the lower class are chained and confined in prison from where they are forced to work or serve as ritual object or crucified for any perceived act of insurrection. This unhealthy relationship between the classes breeds discontent as the slaves are shown from the onset to be restive and to long for freedom, which the coming of Dionysos helps to actualize. It is significant to note that crisis, contradiction; revolution and change in the text follow a predictable dialectical pattern and never result from accidental happenings. In the first place, unequal social formation creates mutual hostility between King Pentheus who represents the upper class and the slaves and the helots who represent the lower class. While Pentheus strives arrogantly to ensure that all he says must be obeyed, he uses chain and every instrument of pain to deal with the slaves who drive economic activity and even to go to the extent of using crucifixion as punishment for slaves when they complain. However, the slaves understand that their condition is not given but man-made and, therefore, hope that one day they will be free. The need to be free causes them to engage from subtle to open agitation. The emergence of Dionysos who is a natural equalizer and reconciler of the warring universe simply heightens their revolutionary activities. The death of Pentheus at the end of the play results to what seems to approximate a classless society where the slaves find themselves in a world of freedom.

\section{REFERENCE LIST}

Dieke, Ikenna. (2010). Allegory and Meaning. Lanham: University Press of America.

Dooley, D. J. (1979). Moral Vision in the Canadian Novel. Toronto: Clarke.

Etherton, Michael. (1982). The Development of African Drama. New York: Africana Publishing Compnay.

Eze, Norbert Oyibo. (2014). "A Comparative Study of Selected Plays of Wole Soyinka and Ola Rotimi," PhD Thesis Submitted to the School of Postgraduate Studies, University of Nigeria, Nsukka.

Gibbs, James. (1986). Modern Dramatists: Wole Soyinka. New York: Grove Press.

Hege, G.F.W. (1967). The Phenomenology of Mind. Trans. J.B. Bailie. New York: Harper and Row Publishers.

Irele, Abiola (1974). "The Season of a Mind: Wole Soyinka and the Nigerian Crisis". The Benin Review. 1: 111122.

Kamenka, Eugene. (1979). Marxism and Ethics. London: Macmillan.

Macintyre, Alisdair. (1971). "Existentialism". Sartre: A Collection of Critical Essays. Ed. Mary Warnock. New York: Double Day and Company Inc.

Maduako, Obi. (1991). Wole Soyinka: An Introduction to His Writing. Ibadan: Heinemann.

Moore, Gerald. (1971). Wole Soyinka. London: Evans Brothers.

Morawski, Stefan. (1977). "Introduction". Marx and Engels on Literature and Art. Eds. Lee Baxandall and Stefan Morawski. New York: International General.

Muoneke, Romanus. (1980). "Adaptation of Greek Tragedies: The Gods are not to Blame (Rotimi) and The Bacchae of Euripides (Soyinka). B.A. Project submitted to the Department of English, University ofNigeria, Nsukka.

Neitzsche, Fredrick cited in Obi Maduako. (1991). Wole Soyinka: An Introduction to his Writing. Ibadan: Heinemann.

Ruy, Jules Chaix. (1968). The Superman: From Nietzsdie to Tailhard de Chardin. Trans. Marina Smyth-Kok. Notre Dame: University of Notre Dame Press.

Soyinka, Wole. (1973). Collected Plays I. London: Oxford University Press.

The Communist Manifesto. www.marxist.org

Williams, Adebayo. (1981). "The Mythic Imagination and Social Theories: Soyinka and Euripides". Okike: An African Journal of New Writing. 18: 36 -44. 